\title{
Errare humanum est: Financial Literacy in European Consumer Credit Law
}

\author{
Vanessa Mak • Jurgen Braspenning
}

Received: 15 December 2011 / Accepted: 9 May 2012 /

Published online: 30 May 2012

(C) The Author(s) 2012. This article is published with open access at Springerlink.com

\begin{abstract}
Examples of financial mistakes made by consumers lend support to the view that systematic mistakes of consumers exist in the EU credit market and that service providers respond strategically to these by redesigning their products. This paper seeks to determine how existing regulation can be improved to ensure consumer protection. Using insights from behavioural economics, this paper argues that financial literacy-that is, knowledge and understanding of complex financial products and skills to navigate the financial market - as a cornerstone for European financial consumer law is problematic. Current regulation is based primarily on information provision to consumers, which should enable them to make appropriate decisions about the risks and suitability of financial products. Although behavioural economics does not necessarily require legal intervention to take other forms than the introduction of information duties, the type of intervention is dependent on the design and needs of a particular market. The EU consumer credit market, in our view, demands more than the current regulation offers in terms of consumer protection. In particular, behavioural studies reveal that consumers generally do not have a sufficient level of financial literacy in order to enable them to make informed, rational decisions. Moreover, behavioural biases have a distorting influence on consumer decision making. The law as it stands, therefore, seems ill-equipped to offer protection to consumers and to prevent them from rash and bad decision making. Reviewing existing regulation and case law, we propose that in the EU law, the Consumer Credit Directive and the Markets in Financial Instruments Directive require updating in order to offer sufficient protection to vulnerable groups of consumers who, on average, have low levels of financial literacy.
\end{abstract}

Keywords Financial literacy · Consumer credit law · MiFID · Consumer Credit Directive

\footnotetext{
V. Mak $(\bowtie) \cdot$ J. Braspenning

Tilburg University, Tilburg, the Netherlands

e-mail: vanessa.mak@uvt.nl

J. Braspenning

e-mail: j.j.a.braspenning@uvt.nl
} 
Errare humanum est. This old Latin phrase is still relevant in modern times. ${ }^{1}$ People made mistakes, make mistakes and will make mistakes. The truth of this statement is proven in consumer cases concerning complex products in which financial services stand out as a category that, by consumers, is often perceived as complex and non-transparent. Consumers are nevertheless enticed to enter into extremely risky credit or investment agreements, with bad outcomes in result. We can see that in the housing market-with the US subprime mortgage crisis as an ultimate example of the consequences that bad decision making can have $^{2}$ - but also earlier on in the investment market, e.g., in the Dutch Dexia litigation concerning retail investment schemes which allowed consumers to invest in the stock market with borrowed money. ${ }^{3}$ It goes to show from these examples that when consumers shop in the financial marketplace, a wrong decision - we will call this a financial mistake - can have irreversible effects for the household. Importantly, a high number of such mistakes can unhinge the stability of the economy as a whole (Braunstein and Welch 2002).

The proposition that consumers are prone to making mistakes in deciding important matters finds wide support in the economic literature. ${ }^{4}$ That is not to say, however, that behavioural economists and neoclassical economists agree on the effects that should be attached to this proposition. Whereas the behavioural school focuses on the solutions that legal intervention can bring for information asymmetries in $\mathrm{B} 2 \mathrm{C}$ relationships and the imperfect rationality of consumers (e.g., Bar-Gill 2008a), critics of this approach challenge the need for such intervention on the ground that competitive markets will achieve better welfare results than can be generated with various forms of government regulation (Epstein 2008 , p. 804). ${ }^{5}$ Another question, if it is assumed that legal intervention is required, is what the substance of this intervention should look like: Is regulation through information duties sufficient, or should further duties (e.g., of "responsible lending") 6 be imposed on banks and other credit and investment providers?

This article focuses on the second question. We adopt the behavioural economics approach as our framework since its position that legal intervention is required, looking at the EU market, seems more realistic than the alternative view that the market will correct itself. The examples of financial mistakes made by consumers and their detrimental effects, such as in the Dexia case and in other cases discussed below, lend support to the view that systematic mistakes of consumers exist in this market and that service providers respond strategically to these by redesigning their products (Bar-Gill 2008a, p. 801). What will need to be determined is how existing regulation can be improved to ensure consumer protection whilst at the same time sufficient space is left for innovation on the supply side. ${ }^{7}$

There is also a more practical reason to focus on the substance of existing regulation. In the last decade, the EU has followed a policy of introducing extensive harmonizing

\footnotetext{
${ }^{1}$ To err is human.

${ }^{2}$ Although, in this example, one may wonder who was ultimately responsible for bad decision making: precrisis, it seems that banks and consumers alike were mistaken in their reliance on the stability of the housing market.

${ }^{3}$ Discussed in Part 2 below, p. 6 ff.

${ }^{4}$ It is accepted not only by behavioural economists but also by its critics; see, e.g., Epstein (2006, p. 111).

${ }^{5}$ Published as an exchange with Bar-Gill's contribution cited in the previous reference.

${ }^{6}$ See below, p. 4.

${ }^{7}$ We come back to this point in Part 4 below. We realize that useful insights can also be gleaned from broader analyses on legal paternalism, but will not discuss these in detail. Support for the proposition in favour of (paternalistic) legal intervention for vulnerable groups in European consumer law can for example be found in Ogus (2010, pp. 65, 68).
} 
legislation in the financial services area, in part with a view to ensuring consumer protection (for a recent overview and discussion of the field, see Grundmann and Atamer 2010). Regulation in the field of consumer credit and investment law has grown extensively, in particular through a set of European measures, most notably the Markets in Financial Instruments Directive (MiFID) of 2004 and the Consumer Credit Directive of $2008 .^{8}$ The MiFID is currently under review, and the expectation is that a revised version (MiFID II) will be introduced in the not-too-distant future. ${ }^{9}$ Rather than the question whether there is a need for regulation, therefore, the more imminent question for the EU market of today is whether existing regulation is sufficiently able to ensure consumer protection.

The problem that we see particularly in European (financial) consumer law is that great emphasis is placed on information requirements. The underlying ideology is that information can "empower" consumers and enable them to make their own assessment of the risks that they are taking (compare Moloney 2010, p. 53 ff.). Although a creditworthiness assessment is sometimes included as an additional requirement, those tests leave plenty of leeway to give credit to consumers who are not in a position to take big financial risks. ${ }^{10}$ For this approach to be successful, therefore, consumers need to be able to digest information and to assess it adequately; in other words, to have a high level of "financial literacy." The measure of financial literacy is to a certain extent abstract, but in short it can be referred to as the consumers' ability to understand complex financial products and their knowledge of and experience with financial products and/or services (Capuano and Ramsay 2011; Hung et al. 2009; Remund 2010). A higher level of financial literacy means that consumers are better equipped the moment they enter the financial marketplace. They are more able to assess the risks of financial products that they consider purchasing.

We will argue that information provision as a cornerstone for European financial consumer law is problematic. Although behavioural economics does not necessarily require legal intervention to take other forms than the introduction of information duties (see BarGill 2008a, pp. 753-754), the type of intervention is dependent on the design and needs of a particular market. The EU consumer credit market, in our view, demands more than the current regulation offers in terms of consumer protection. Studies in the field of Behavioural Finance reveal that consumers generally do not have a sufficient level of financial literacy in order to enable them to make informed, rational decisions. Moreover, heuristics and biases have a distorting influence on consumer decision making even when sufficient financial knowledge and skills are present. The law as it stands, therefore, seems ill-equipped to offer protection to consumers and to prevent them from rash and bad decision making. The question is how it can be improved.

The article is structured as follows. Part 2 will describe the legal framework for consumer protection in European consumer credit law and the position of financial literacy in this framework. A comparison will be made of how different legal systems - EU law, and Dutch and English law as national examples - weigh financial literacy against other factors that can ensure consumer protection against financial mistakes (e.g., a creditworthiness assessment or a duty to warn). Part 3 will discuss insights from the field of financial literacy and behavioural studies. It will give an overview of financial literacy surveys from Europe and from other parts of the world, highlighting which groups of consumers are more or less literate and how this influences their decision making. In Part 4, we come back to the legal

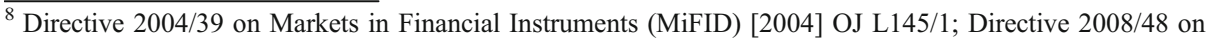
Consumer Credit Agreements (Consumer Credit Directive) [2008] OJ L133/66.

${ }^{9}$ Compare European Commission (2010).

${ }^{10}$ Compare Consumer Credit Directive, Art. 9.
} 
framework. Where should consumer credit law strike the balance between, on the one hand, consumer empowerment through the enhancement of financial literacy and, on the other hand, consumer protection through, e.g., creditworthiness assessments or duties to warn? The MiFID, which is up for review, will serve as our prime example. ${ }^{11}$

\section{Financial Literacy and "Responsible Lending" in European Consumer Credit Law}

Information provision to consumers is a central element in European consumer credit law. It reflects the main policy of European consumer law, which is that consumers should be "empowered" through information and advice to enable them to make an adequate assessment of the product that they are thinking of purchasing (cf. Moloney 2010, p. $53 \mathrm{ff}$.; Rott 2009 , p. 183). As the examples in the introduction have shown, this is not enough. Consumers need more protection, for example in the form of creditworthiness assessments, advice or warnings. This, also, is reflected in European legislation, such as the Consumer Credit Directive and the MiFID, in which provisions are included that reflect a policy of "responsible lending" or that include a "suitability check."12 The term "responsible lending" refers to a duty of banks and other credit providers to act as "good creditors," which in these instruments is translated - more concretely-into obligations to assess the creditworthiness of clients through the consultation of centralised databases ${ }^{13}$ and sometimes a duty to warn. ${ }^{14}$ MiFID's requirement that investment firms - in given circumstances — should check the suitability of a product for a client has some overlap with this duty. ${ }^{15}$

The balance between information provision and "responsible lending" or "suitability," however, is not an easy one to strike. Practically, banks and consumers have different stakes in the market, which is reflected in consumer law. Banks are generally willing to be more open as to whom they give credit and on what terms (see Council of Mortgage Lenders UK 2011; European Commission 2011). Consumer groups, on the other side, emphasize the need for consumer protection, e.g., through information and advice requirements or duties to warn (European Commission 2011). However, the picture is not as black and white as this. Greater consumer protection can also have negative backlashes for consumers. Should stricter consumer protection measures be adopted, the result can be that credit becomes unavailable to certain - low-income - groups of society. That can be detrimental to the welfare of society where homeownership counts as a stabilizing factor and is encouraged by governments, often through subsidizing or tax benefits. Also, the financial system may benefit from greater availability of credit. Although it can mean that a small number of consumers are worse off for entering into agreements that they cannot afford, greater market participation has been shown to have positive effects on asset pricing (Moloney 2010, p. 77), and it can have the same effect on the cost of credit and on product innovation by suppliers.

These different viewpoints have come to a clash before, most notably in the debate surrounding the review of Directive 87/102 on Consumer Credit in 2002 (see Rott 2009, pp. 184-187). The outcome, for now, is that the balance appears to have been struck in favour of information provision. The reviewed version of the Directive-Directive 2008/48 on

\footnotetext{
${ }^{11}$ MiFID II consultation (n. 9). See also 'Proposal for a Directive of the European Parliament and of the Council on credit agreements relating to residential property', COM(2011) 142 final (31 March 2011).

${ }^{12}$ Consumer Credit Directive, recital 26; see also Art. 8. Also, Proposal for a Directive of the European Parliament and of the Council on credit agreements relating to residential property, Art. 14.

${ }^{13}$ Compare review proposal Consumer Credit Directive, pp. 15-16.

${ }^{14}$ Compare MiFID, Art. 19(4).

${ }^{15}$ See further below, p. 26.
} 
Consumer Credit - does not contain a general provision on "responsible lending," apart from a reference to the general concept in recital 26 preceding the Directive. A general duty to act as a "responsible lender" was thought to be unacceptably burdensome on banks, in particular since the initial proposal was rather vague on what was included in such a duty (Rott 2009, p. 185). Not surprisingly, therefore, the provisions in the Consumer Credit Directive that specify duties of responsible lending are sparse: In fact, there is only Art. 8 on assessing the creditworthiness of consumers. All other provisions centre on the provision of information to the consumer to enable him to make his own decision on whether "the credit agreement is adapted to his needs and to his financial situation" (Art. 5(6) of the Directive). Similarly, the MiFID contains only a few provisions that could be brought under a policy of "responsible lending," or responsible investment selling in this case: ${ }^{16}$ Art. 19(1) obliging investment firms to act honestly, fairly, and professionally in accordance with the best interests of its clients and to comply, in particular, with the specific "principles"17 set out in paragraphs $2-8$ of that article; Art. 19(3) on risk warnings; and Art. 19(5) obliging investment firms to warn should they find the product not suitable for the client. ${ }^{18}$

Contrary to the EU approach which seems fixed on information provision, it appears that national private laws provide a basis for a more "responsible" practice of banks in credit relationships, although the extent differs (compare Mak 2011). Civil law systems, such as Dutch or German law, are able to offer greater protection to consumers by adopting a duty of care for banks towards their clients. English law, on the other hand, is reluctant to go beyond the minimum information duties prescribed by legislation and certainly does not lean towards a general duty of care. However, there is an alternative route for consumers via the Financial Ombudsman Service (FOS), where cases are judged on the basis of fairness.

To illustrate these differences, we will now discuss some paradigm cases from Dutch and English laws and will compare these to the solutions offered by the EU regulation. It should be noted that since the cases here discussed involved combined products - e.g., credit and investment, or credit and insurance - the balance of information duties with other factors such as advice duties and creditworthiness may be struck differently in simple credit transactions. The latter are generally regulated by the Consumer Credit Directive, whereas combined credit and investment transactions by investment firms fall under the more detailed provisions of the MiFID. ${ }^{19}$ Nevertheless, the relation between regulation through national (private) laws and European regulation brings up similar questions for a wide range of credit products. Whether they are regulated by the Consumer Credit Directive, the MiFID, or more specific regimes (as may be the case, e.g., with mortgage credit once the proposed Mortgage Credit Directive is implemented), these rules will always interact with rules of national laws, often of a private law nature. Therefore, the approaches of domestic systems with regard to information provision and duties of care that we discuss can be illustrative for the regulation of credit products in the financial services market as a whole.

\footnotetext{
${ }^{16}$ Note that credit agreements with investment firms (Art. 4(1) of the MiFID) are excluded from the scope of the Consumer Credit Directive (Art. 2(2)(h) of that Directive). They are "ancillary services" in the sense of Art. 4(1)(3) of the MiFID, specified in Section B of Annex I, and therefore governed by the MiFID regime. ${ }^{17}$ Rules seems more apt.

18 Note also Art. 19(9) of the MiFID which stipulates that in cases where an investment service is offered as part of a financial product which is already subject to other provisions of EU legislation (e.g., the Consumer Credit Directive), this service shall not be additionally subject to the obligations set out in Art. 19 MiFID.

${ }^{19}$ This difference concerns in particular the protective duties laid down in Art. 19(4) and (5) of the MiFID. See further below, p. 23.
} 
The Dexia case concerned retail investment schemes which basically allowed consumers to invest in the stock market with borrowed money. ${ }^{20}$ These schemes were aimed to make the stock market accessible to the "man on the street," and they were actively marketed in the late 1990s with promising names like "Triple profit scheme" or "Sprintplan." 21 The schemes were in fact a combination of a credit and an investment agreement: The consumer would borrow a certain amount of money, which was invested in stocks; these stocks, in turn, functioned as security for the repayment of the debt and the interest that accrued on it by the consumer. This could be very lucrative when the stock market went up and the consumer would make a profit over the entire stocks portfolio. However, there was also a dark side to the scheme: If the stock market went down, the consumer could be left with a portfolio that was too low in value to repay the debt. In that event, the consumer would be left with a socalled restschuld, or "remaining debt." This is indeed what happened for a large number of consumers when the stock market made a steep fall in 2000. The result was an explosion of litigation, part of which was settled in a collective settlement (the "Duisenberg-regeling") and part of which continues until today (Tzankova 2012).

The question whether investment firms such as Dexia could be held liable for the losses suffered by these consumers was addressed by the Dutch Supreme Court in its judgments of 9 June 2009, of which De Treek $v$. Dexia can serve as a paradigm case. Three grounds for liability were proposed by the claimant: misleading advertising, misrepresentation (or $d$ waling in Dutch law), and a duty of care. We will leave aside the misrepresentation claim since it is contested whether the Court was correct in its application of the law on this point, ${ }^{22}$ which is a question that pertains to dogmatic points of Dutch private law. What is more interesting, for our purposes, is to consider the relation between the misleading advertising claim - which is grounded in EU law — and the duty of care. The Court held that there could be no claim on the basis of misleading advertising, referring to the "average consumer" of EU law who is "reasonably well-informed and reasonably observant and circumspect." 23 This reference consumer sets the standard for misleading advertising and also for the later enacted European legislation relating to unfair commercial practices, ${ }^{24}$ as well as for the information duties derived from the Consumer Credit Directive and the MiFID. ${ }^{25}$ For this type of consumer, the information provided by Dexia was deemed sufficient for the consumer to understand the product and its risks. ${ }^{26}$ This part of the judgement, therefore, confirms the importance of the consumer's financial literacy.

However, the Court did not leave it at this. It held that under general Dutch private law, the special relationship between a credit/investment provider and his client entailed a duty of care towards the client based on the general principle of "reasonableness and equity" (or

\footnotetext{
${ }^{20}$ Dutch Supreme Court (HR) 5 June 2009, LJN: BH2815 (De Treek v. Dexia). Similar judgments appeared with respect to two other investment firms, Levob and Aegon; see HR 5 June 2009, LJN: BH2811 (Levob); HR 5 June 2009, LJN: BH2822 (Aegon). For a comprehensive analysis, see-in Dutch-van Boom and Lindenbergh (2010).

${ }^{21}$ Some 300 different varieties of these schemes existed (cf. van Boom and Lindenbergh 2010, p. 188).

22 Ibid.

${ }^{23}$ Cf. Case C-210/96 Gut Springenheide and Rudolf Tusky v. Oberkreisdirektor des Kreises Steinfurt [1998] ECR I-4657, at [31].

${ }^{24}$ Directive 2005/29 concerning business-to-consumer unfair commercial practices in the internal market [2005] OJ L149/22, Art. 5.

${ }^{25}$ In Dutch law, compare Art. 4:19 Wet op het financieel toezicht (Wft); formerly Art. 30 Wet op de financiële dienstverlening (Wfd).

${ }^{26}$ De Treek v. Dexia (n. 20), [4.5.3]. Also, HR 5 June 2009, Aegon (n. 20).
} 
"good faith"). ${ }^{27}$ The provider, as the expert party, is obliged to take account of the interests of the consumer and to protect him against the risks associated with his lack of insight or his own rash decision making. More specifically, this means that banks and investment firms are obliged to warn consumers about the specific risks of a product, to investigate the financial position of the client, and, if the circumstances demand it, even advise the client against purchase of the product. ${ }^{28}$ This duty of care applies not only to advice relationships (as it would under the MiFID) but also to "unadvised sales," as seen in the Dexia case where consumers purchase investment products on the basis of advertising and without a further advice relationship with the bank.

This judgement illustrates how national private law can go further than the EU law in its protection of the "average consumer." The MiFID — in accordance with the general approach to misleading advertising of the UCP Directive - places the responsibility with the consumer to act rationally on the basis of the information provided by the investment service provider. In the absence of a special relationship, such as an investment advice contract or portfolio management, it is left to the consumer to decide whether a specific product or service is appropriate for him (Kruithof 2011, p. 134). ${ }^{29}$ The Dutch "average consumer" in financial services, as the Dexia case shows, can rely on a much broader duty of care based on general private law. On that ground, a professional financial service provider is obliged not only to provide fair, clear, and non-misleading information and to check the consumer's previous experience in the investment market (cf. Art. 19(2) and (5) of the MiFID) ${ }^{30}$ but also to assess the appropriateness of the specific product or service in light of the consumer's financial position. If the consumer's financial position does not warrant the risk, the investment service provider should advise him against the purchase of the product.

Such a wide-ranging duty of care is not foreign to Dutch investment law. Earlier case law in the area of option trade introduced an even broader duty of care, obliging investment service providers to deny a consumer the purchase of options if that consumer did not fulfil a minimum capital requirement ("margin requirement"; Cherednychenko 2011, p. fn. 30). That duty, subsequently codified in supervisory legislation, applies regardless of the consumer's existing knowledge and experience of the options market (Jansen 2010; Kruithof 2011, p. 157). ${ }^{31}$ Noteworthy, furthermore, is that German law tends to adopt a similarly proconsumer stance on duties of care owed by banks and investment firms to their investment clients. Recent case law from the BGH confirms that complex, high-risk products demand a greater responsibility from investment service providers to ensure that their clients are aware of the risks involved in the product and are willing to take them. ${ }^{32}$

The protective stance adopted in Dutch law also applies to simple consumer credit products (i.e., not combined with investment or insurance). With regard to those, the legislator has been proactive: Since 2006, an explicit duty to test the creditworthiness of consumers and to deny credit where there is a risk of over-indebtedness is laid down in legislation. ${ }^{33}$ Regulation therefore seeks to prevent vulnerable consumers from entering into

\footnotetext{
${ }^{27}$ De Treek v. Dexia (n. 20), [4.8.4].

${ }^{28}$ Cf. De Treek v. Dexia (n. 20), [4.8.1]; Levob (n. 20), [4.5.4], [4.5.6] and [4.5.10].

${ }^{29}$ Cf. Art. 19(4) and (5) of the MiFID.

${ }^{30}$ Implemented through art. 4:23 and 4:24 Wft.

31 Art. 86 Besluit gedragstoezicht financiële ondernemingen (Bgfo), which specifies the duties laid down in Art. 4:25 Wft.

${ }^{32}$ Ille Papier v. Deutsche Bank, BGH 22.03.2011 XI ZR 33/10, in which the protected party was not even a consumer but a medium-sized business. For a more detailed discussion, see Mak (2011).

${ }^{33}$ See Art. 51(2) Wet financiële dienstverlening, replacing Art. 28 Wet consumentenkrediet. The provision was replaeed by Art. 4:34 Wft in 2007, which in substance provides the same.
} 
credit agreements which they are likely to be unable to pay off. German law, in contrast, does not oblige providers to deny credit where there is a risk of over-indebtedness and is therefore less strict with regard to credit than with regard to investment products. ${ }^{34}$ We will come back to this distinction in Part 4. Suffice for now to conclude that Dutch law is placing duties on banks and other credit and investment providers to ensure that they act responsibly towards consumers and that German law is (in part) doing the same.

\section{English Law: Barnes v. Black Horse $e^{35}$}

For English law, the situation is different. Here, a paradigm case is provided by the so-called PPIs. A PPI, or Payment Protection Insurance, is an insurance policy often sold in combination with credit agreements. It aims to cover repayments if the borrower suffers an insured event, such as an accident, sickness, unemployment, or death (see Howells 2010, p. 631). The fact that these policies are often sold secondary to the supply of credit creates a disadvantageous position for consumers, who will either not be inclined to shop around-which often also does not happen because these policies are sold to purchasers who are vulnerable and already unlikely to compare products - or who will purchase the product for other reasons, e.g. because they are concerned that they will otherwise not have access to the source of credit (Howells 2010, pp. 631-632). Many consumers therefore end up with products that are not in their interest (e.g., not needed or too expensive). Following complaints, the Financial Services Authority (FSA) who is responsible for supervision of the retail financial market is trying to stop such practices by imposing fines and by developing behavioural guidelines for the industry (FSA 2009). The FSA's intervention has led to compensation schemes which offer relief to consumers who have purchased such PPIs. ${ }^{36}$

In the meantime, consumer claims with regard to PPIs have resulted in litigation, both before the common law courts and before the FOS. It is interesting to see that the assessment of liability leads to different results depending on the forum that is chosen. For the common law perspective, we can refer to a recent High Court judgement, in the case of Barnes $v$. Black Horse. ${ }^{37}$ The claimants were a husband and wife who had bought PPI policies in relation to three different loans with Black Horse, Ltd. They complained on six grounds: (a) They were sold PPI policies when they already had sickness benefit; (b) the policies were very expensive; (c) Black Horse did not advise them to shop around for PPI policies; (d) they were told the policies were compulsory when they were not; (e) Black Horse did not establish that the policies were in their interest; and (d) Black Horse failed to follow the terms of certain documents. ${ }^{38}$ Their claim failed. According to Judge Waksman, QC, neither a fiduciary duty nor a duty of care owed by Black Horse to the Barneses could be established. ${ }^{39}$ This is due to the limited circumstances in which English law acknowledges such duties, which requires that the defendant has through its statements or actions assumed responsibility towards the claimant. ${ }^{40}$ The words of Judge Waksman with regard to the duty of care illustrate this:

\footnotetext{
${ }_{34}^{34}$ Compare BGH, IX ZR 130/88, NJW 1989, 1276; BGH, III ZR 37/88, 16.3.1989, NJW 1989, 1665.

${ }^{35}$ Barnes v. Black Horse Ltd. [2011] EWHC 1416 (QB).

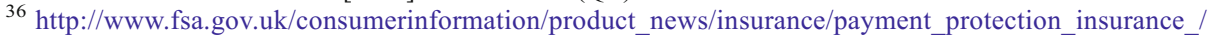
ppi_judgment_accepted.

${ }^{37} \mathrm{Ibid}$.

${ }^{38}$ Ibid., at [10].

${ }^{39}$ Ibid., at [13] ff., [32] ff.

${ }^{40}$ Cf. Donoghue v. Stevenson [1932] UKHL 100; [1932] AC 562; Caparo Industries plc v. Dickman [1990] UKHL 2; [1990] 2AC 605.
} 
What is conspicuously absent from the plea of a duty of care here is any factual basis relating to this particular case from which it could be drawn. It is not said, for example, that Black Horse assumed a responsibility here to give particular advice on the facts of the cases. Indeed (...) it is not suggested that Black Horse was either asked to, or was expected to or purported to, give advice of any kind. ${ }^{41}$

That conclusion confirms that English law in general does not tend to protect weaker parties, barring specifically identified circumstances, and therefore stays close to the protection of an "average consumer" in EU law. Illustrations of that attitude can be found in cases concerning undue influence in suretyship relationships, ${ }^{42}$ and more generally in the absence of a general principle of good faith in English law. For credit and investment services, the result is that private law offers very little protection to consumers. The MiFID rules, implemented in English law through the FSMA, offer some protection, but that protection is limited in cases other than advice relationships or portfolio management. ${ }^{43}$ Since the court established that the Barneses did not have an advice relationship with Black Horse, ${ }^{44}$ therefore, the final decision on the appropriateness of the product was their own responsibility.

The Barneses had perhaps better have made a claim before the FOS. Other consumers did, with the total amounting to 49,169 in 2009 . Of these claims, $89 \%$ were decided in favour of the consumer (FOS 2010, pp. 34, 51; Howells 2010, p. 633). The big advantage here is that the FOS is not obliged to decide on the basis of common law: They can go beyond the law and decide cases on the basis of what is fair and reasonable, including good practice, voluntary industry standards and codes (even if superseded by legislation), and the FSA Handbook (Howells 2010, p. 634). This often leads to more consumer-friendly decisions than the common law routes of misrepresentation, breach of duty, or breach of fiduciary duty.

\section{Interim Conclusion}

This brief overview of domestic cases confirms that financial mistakes by consumers are common and, also, that finding an appropriate legal solution is not straightforward. Some national laws have founds solutions through private law, but one may wonder whether private law remedies are sufficient: This way, consumers will need to make a complaint or be stuck with their losses. Perhaps more, or different, regulation is necessary.

The use of information duties as a means of regulation seems crucial in this context. Both in the Dutch and in the English cases, information had been provided to consumers. That is in accordance, also, with the European rules governing consumer credit and investment services. ${ }^{45}$ However, the cases show that information was not sufficient for protecting consumers from bad decision making. Theoretical support for that conclusion can furthermore be gleaned from behavioural economics studies which have cast doubts on the effectiveness of information duties as means of consumer protection (Bar-Gill 2008a; Ben-Shahar and Schneider 2010). The question is, therefore, whether information duties can be remodelled to become more effective (e.g., by obliging providers to disclose not just

\footnotetext{
${ }^{41}$ Ibid., [34].

42 Royal Bank of Scotland v. Etridge (No. 2) [2001] UKHL 44; [2002] 2AC 773; Barclays Bank v. O’Brien [1993] UKHL 6; [1994] 1AC 180.

${ }^{43}$ Cf. Art. 19(4) and (5) of the MiFID.

${ }^{44}$ Barnes v. Black Horse (n. 35) at [34].

${ }^{45}$ Art. 19(2) of the MiFID; Art. 4, 5 and 6 of the Consumer Credit Directive.
} 
information on the attributes of a product but also information on individual uses of the product) or whether they should be supplemented with other modes of regulation, such as stricter duties to warn or perhaps even duties to withhold credit from consumers if products are not suitable for them in light of their financial position or their inexperience with the credit or investment market.

This question - which basically asks how much responsibility for bad decision making should lie with consumers themselves - requires that we have insight in the abilities of consumers to safely navigate the financial market. We will focus our enquiry, therefore, on the financial literacy of consumers.

\section{Financial Literacy}

What is financial literacy? An increasing number of scholars engaging in research on financial markets refer to the term, yet it is not consistently used. Studies often concentrate on the relationship between financial knowledge and the quality of decision making on the consumer side. A general, and perhaps not surprising insight, is that one's level of knowledge and experience can positively contribute to sound financial decision making (Van Rooij et al. 2007). One element that is clear is that financial literacy in these studies involves more than plain literacy which, according to its general meaning, can be defined as "the ability to read and write." Based on this definition, one could simply say that financial literacy is the ability to understand and act within a financial context. Although this view is found in some instances in the US literature (e.g., Adkins and Ozanne 2005), it does not seem to have found wide support. Not only does it assume that very basic literacy skills are sufficient for consumers to navigate the financial market: it also does not explain what can be expected from a financially literate person.

The better view seems to be that financial literacy encompasses a bundle of elements that are relevant for sound financial decision making, including knowledge and experience, but also other elements. Which elements those are, however, is open to debate. Among scholars, professional parties, and policy makers in the field of behavioural finance, there is no clear consensus about the elements that should be included in a concept of financial literacy. Some studies focus more on knowledge, whilst other studies stress the significance of sufficient (financial) skills. Alternative terms like financial capability, mostly used in the UK, and financial sophistication are used interchangeably with the term financial literacy, even though they sometimes cover wider ground or are themselves used in convertible ways (Dixon 2006; Oehler and Werner 2008, p. 260).

To enable a comparison between different markets or jurisdictions, the recent metaanalysis of the use of the term financial literacy by Remund can offer a useful framework. The study conducted by him looked at more than 100 different definitions of financial literacy across multiple countries and various types of studies (Remund 2010). Based on an analysis of the different definitions of the term, Remund suggests that future research conceptualizes financial literacy as follows:

Financial literacy is a measure of the degree to which one understands key financial concepts and possesses the ability and confidence to manage personal finances through appropriate, short-term decision-making and sound, long-range financial planning, while mindful of life events and changing economic conditions. (Remund 2010, p. 284)

This conceptualization encompasses a mix between knowledge, skills, and confidence in a financial decision-making context. A subsequent question that has to be answered is what 


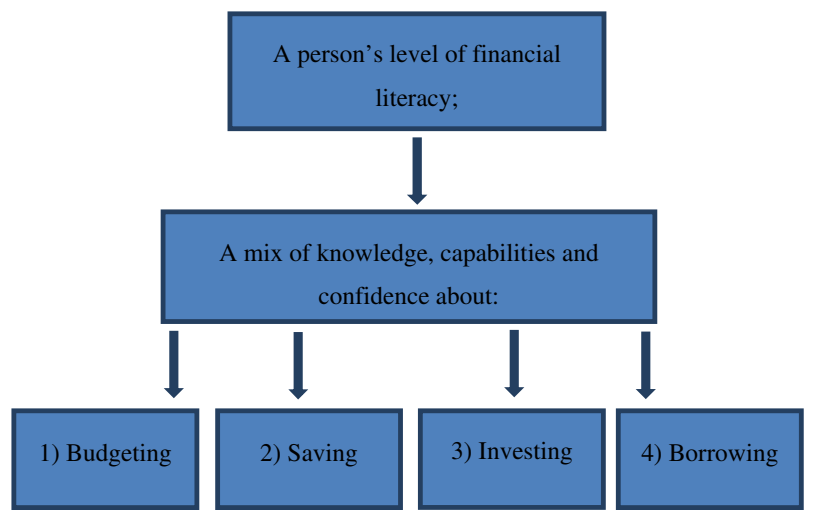

Fig. 1 The picture of financial literacy

can be expected from a financially literate consumer? Also on this point, Remund's study is instructive. The general conceptualization of financial literacy can be translated into an additional operational definition to be able to measure financial literacy in a tangible way. A majority of prior research analysed by Remund uses four categories of operational definitions, namely, budgeting, saving, investing, and borrowing (Remund 2010, p. 288). Combining these with the general conceptualization, a financially literate consumer needs to possess knowledge and skills in these four areas, in combination with sufficient confidence that allows him to actually act in the marketplace. This leads to the following overview (Fig. 1).

This kind of operational definition can be a basis for empirical studies of specific markets, from which insights can be gleaned on consumer behaviour and decision making which in turn can provide guidance for regulation. Particularly in the USA, a range of studies has been carried out of financial literacy in specific markets, suggesting that there are links between financial literacy and financial mistakes made by consumers (Part 3a). The relevance of such studies for Europe is confirmed by surveys in the Netherlands, Germany, and the UK, which consistently show that consumers on average have low levels of financial literacy (Part 3b).

Financial Literacy: Insights for Consumer Decision Making

Studies on financial literacy and financial decision making often use a standard format for the various types of financial literacy research. At first a survey is conducted. Sometimes a sample of the general population is analysed; in other cases, the focus is on a subpopulation like students. The majority of questions in these surveys are related to elementary financial subjects and concepts based on various operational constructs. ${ }^{46}$ A clear example is the next question about interest compounding that is used in a recent financial literacy survey by Van Rooij et al. (2007).

Suppose you had $€ 100$ in a savings account and the interest rate is $20 \%$ per year and you never withdraw money or interest payments. After 5 years, how much would you have on this account in total?

(a) More than €200; (b) Exactly €200; (c) Less than €200; (d) Do not know; (e) Refusal

\footnotetext{
${ }^{46}$ Note that the studies that will be discussed further on in this article did not use the conceptualization of financial literacy by Remund (2010) in their empirical research. Nevertheless, some studies use concepts that come close to Remund's definition. Good examples are the work by Van Rooij et al. (2007) and the study of Fazli Sabri et al. (2010).
} 
This was one of the easier questions in that particular survey. ${ }^{47}$ The majority of the other questions are more difficult. Nevertheless, it has to be taken into account that such questions are still relatively easy compared to the complex financial decisions households are facing today. ${ }^{48}$ Besides financial questions, questions are also asked about the personal situation of the respondent and his financial decision-making/behaviour. That includes, e.g., questions related to mortgage planning or stock market participation. On the basis of the obtained data about the relationship between one's level of financial literacy and the quality of decision making, a quantitative analysis is performed in order to find evidence about the link between knowledge and behaviour.

The relationship between financial literacy and the quality of a decision may differ depending on the type of decision that is made. An interesting example can be found in research about retirement saving. In this context, the influence of financial literacy is associated with financial planning. According to Lusardi, retirement planning is a powerful indicator of wealth accumulation: Those who plan have more than double the wealth of those who have done no retirement planning (Lusardi 2008, p. 13). It appears that individuals over the age of 50 with a higher level of financial literacy tend to have thought more about their retirement plan than less financially literate individuals (Lusardi and Mitchell 2007, p. 39). These so-called planners are shown to have more knowledge about elementary financial concepts like inflation and risk. This knowledge is in turn necessary with respect to investment decisions that have to be taken in a retirement plan.

Specifically relevant for this article are the consequences of (low) financial literacy for debt-related decisions made by consumers. According to Gerardi et al. (2010), an individual's level of financial literacy is a good predictor for the possibility that a consumer eventually will default on his debt: "We find a large and statistically significant negative correlation between financial literacy and measures of mortgage delinquency and default" (Gerardi et al. 2010, p. 4). ${ }^{49}$ People default on mortgages by not being able to pay their monthly payments anymore. This is exactly what happened during the 2007 US housing crisis. The link between financial literacy and the credit crisis is also made by other researchers. According to Boeri and Guiso (2008), financial literacy is one of the factors that contributed to the 2007 subprime mortgage crisis in the USA ${ }^{50}$ : "Financial literacy is particularly low among those who have taken out subprime mortgages" (Boeri and Guiso 2008, p. 38). These findings confirm that a strong link between financial literacy and the quality of debt-related decision making exists. The influence of financial literacy goes even further according to Bucks and Pence, who argue that consumers that are having problems with acquiring a mortgage are often hindered by a low level of financial literacy (Bucks and Pence 2008, p. 12).

\footnotetext{
$\overline{47}$ The answer to the question is (a).

${ }^{48}$ The example question was about a fixed interest structure. More complex financial products with an adjustable rate structure are also commonly provided to consumers.

${ }^{49}$ Numerical abilities, as a specific part of one's basket of financial literacy, are the most important factor of influence in the quality of mortgage-related decision making.

${ }^{50}$ It should be stressed that (insufficient) financial literacy is not the only, nor the direct, cause of the 2007 crisis. Factors such as the democratization of credit under the Clinton and Bush administrations combined with relatively low (variable) interest rates made it possible for a large group of consumer to acquire access to mortgages to finance home acquisitions. Financial literacy becomes relevant, then, as an indirect cause of the crisis. Due to the low levels of financial skills and knowledge that are required in the financial marketplace, many households were persuaded to acquire subprime loans in the early 2000s. Unfortunately, these loans were often not very suitable to the financial position of these households. As a result, many households defaulted on their debts and a systematic financial crisis ensued.
} 
Relevant studies, further, concern the link between financial literacy and credit cards. Lusardi and Tufano have carried out a study focusing exclusively on consumers' financial knowledge and capabilities with respect to credit card debt. They showed that the level of debt-related financial literacy ("debt literacy") is relatively low in the USA (Lusardi and Tufano 2009, p. 1). Importantly, according to the researchers, low levels of financial literacy are associated with high unfavourable credit card fees. In general, low-literate consumers are paying almost $50 \%$ higher fees compared with more financially literate consumers. This is especially striking given the fact that there is also a strong link between financial literacy and over-indebtedness. The less literate often have problems with the management of their household debt. Finally, Lusardi and Tufano argue that almost one third of the costs that consumers face in this context are caused by insufficient financial knowledge (Lusardi and Tufano 2009, p. 25).

Therefore, both for debt- and equity-related decisions, the influence of the level of financial literacy appears to be significant. The higher the level of financial literacy, the better and the more optimal decisions should be made. Conversely, the less financially literate consumers are more likely to make financial mistakes. This finding does not need to be problematic if only a small group of consumers qualifies as illiterates. Unfortunately, this is not the case. The next section will look at the incidence of financial literacy in three European countries.

Financial Literacy in the Netherlands, Germany, and the $\mathrm{UK}^{51}$

Having discussed case law from the Netherlands, Germany, and the UK in Part 2 of this article, the following can be said about financial literacy in these countries.

\section{The Netherlands}

As early as 2006, Van Rooij encountered a significant lack of sufficient levels of financial literacy among the Dutch population in general (Van Rooij 2006, p. 54). At the same time, the Dutch central bank, DNB, introduced a financial literacy module in its annual household survey. Since then, Van Rooij, often in corporation with other researchers, analysed the results of the DNB household survey in order to get a more thorough understanding of the level of financial literacy among the Dutch population. A series of research reports by Van Rooij et al. $(2007,2009,2011)$ reveals that the situation has not improved since 2006. An interesting aspect is the fact that Van Rooij et al. made a distinction between relative basic and more sophisticated aspects of financial literacy. ${ }^{52}$ More than $40 \%$ of the Dutch households in this study were able to answer all the five basic financial literacy questions correctly (Van Rooij et al. 2009, p. 27). Another $35 \%$ made only one mistake. At the same time, the researchers found that the Dutch had much more problems with complex financial subjects like the riskiness of investment opportunities. Only $5 \%$ of the respondents were able to make no mistakes in this part of the questionnaire (Van Rooij et al. 2009, p. 8).

\section{Germany}

A nationwide financial literacy survey, called "SAVE," by the Mannheim Institute for the Economics of Aging has been held in Germany since 2007. In comparison, the Dutch DNB

\footnotetext{
${ }^{51}$ See, for a good overview of various countries, OECD (2005, p. 42). Not only in the Western world but also elsewhere, this problem is recognized; see, e.g., Bond et al. (2010, pp. 16-24).

52 The example on page 13 of this article is a good example of a basic financial literacy question.
} 
household survey was a bit more sophisticated and extensive, with a total of 16 questions, whereas the German survey contained only three quite basic financial literacy questions (Bucher-Koenen and Lusardi 2011; Pahnke and Honekamp 2010). Nevertheless, the basic questions that were asked in the German survey show sufficient similarity with the basic questions in the DNB Household survey. In addition, more than 2,000 German households participated in the SAVE survey. The latter makes the SAVE survey the only useful financial literacy study that has been conducted in Germany anno 2012. The results of this study show a clear pattern. Surprisingly, only $53 \%$ of the households in the German study were able to answer all three relatively simple questions in a correct way. At the same time, a large group of German households provided zero correct answers or indicated that they did not know the answer to the questions in the survey (Bucher-Koenen and Lusardi 2011, p. 11).

\section{The UK}

In September 2010, a nationwide online household survey was conducted by YouGov Consulting among 2,500 households in the UK (Disney and Gathergood 2011; Gathergood 2012). Like the German survey, three basic questions were asked in order to get insights into the financial literacy of the British population. ${ }^{53}$ Thirty-five per cent of the sample was able to answer all three questions correctly, whilst $11 \%$ of the respondents did not provide a single correct answer. The results of the YouGov survey are, to a certain extent, in line with prior research by the Financial Services Authority (FSA) in the UK. In a 2006 study, the FSA did research about the concept of financial capabilities among British households. Although there are conceptual differences between the term financial literacy and the term financial capabilities as used by the FSA, this study made clear that there are indeed weak spots with regard to the financial knowledge and skills of a substantial part of the British households (FSA Report March 2006, p. 134) A second study by O'Donnell compared the results from the UK FSA survey with evidence from Ireland. She concluded that the Irish situation is very much similar to the situation in the UK (O'Donnell 2009, p. 47).

These studies conducted in the Netherlands, Germany, and the UK highlight the serious lack of sufficient financial knowledge and skills among these European households. There is still a large group of consumers in these countries that has serious difficulties with basic financial concepts. The Dutch study reveals that for more sophisticated concepts, the lack of knowledge and skills is even more striking.

It is interesting to note that financial illiteracy is often not equally spread among the population. Research indicates that there are particular subpopulations that are more likely to suffer from a lack of financial knowledge and skills. A set of personal and socioeconomic factors can determine the level of financial literacy. These include age, gender, socioeconomic class, and ethnicity. ${ }^{54}$ As to age, people younger than 30 and older than 60 generally score the worst on basic financial literacy questions (Bucher-Koenen and Lusardi 2011, p. 13; Van Rooij et al. 2009, p. 28). Middle-aged persons have the highest levels of financial literacy. The results from van Rooij et al. concentrating solely on more advanced financial literacy concepts measured in their research show a slightly different picture. With regard to sophisticated financial literacy questions, the worst performing group is younger than

\footnotetext{
53 This survey was primarily focused on debt-related financial knowledge and skills.

${ }^{54}$ Contested, but also relevant, may be the region of origin. Some authors find a straight influence of region, for example Bucher-Koenen and Lusardi (2011, p. 13; also Monticone 2010, p. 409). Other researchers did not find a region effect in their research; see, for example, Fazli Sabri et al. (2010, p. 464).
} 
40 years (Van Rooij et al. 2009, p. 29). In terms of gender, studies indicate that men generally score better on financial literacy questions than women (among others, Van Rooij et al. 2009, p. 28). The third factor of influence, socioeconomic class, is a broad concept that can include various aspects like education, income, home ownership, and employment. The previously mentioned studies about the Netherlands and Germany discuss the influence of income and education. People with a higher level of education are more likely to have a higher level of financial literacy. A steep increasing line is visible from primary school to the university level (Bucher-Koenen and Lusardi 2011, p. 14; Van Rooij et al. 2009, p. 28). In addition, evidence is found of a positive effect of income on the level of financial literacy (Bucher-Koenen and Lusardi 2011, p. 15). Finally, ethnicity can also be a factor of influence. It should be noted that this determinant has not been extensively tested in European research, but authors from North America and Asia have come up with interesting data in this context. Ethnic minorities like Afro-Americans, Hispanics, and Native Americans in the USA, and people with a Chinese background in Malaysia, score worse on financial literacy tests (Fazli Sabri et al. 2010, p. 461; Lusardi 2008, p. 8). Given the fact that countries like the Netherlands, Germany, and the UK share the characteristics of having a multicultural society, it is likely that similar findings can be made for other countries in Western Europe. In addition, recent financial literacy research among students in the Netherlands reveals that for this group, ethnicity is indeed a significant determinant of one's level of financial knowledge and skills (Braspenning 2012, p. 82). ${ }^{55}$

\section{Financial Literacy in European Consumer Credit Law: Integrating the Insights from Behavioural Economics}

We have seen in Part 3 that financial literacy studies indicate that a lack of financial literacy is an important cause of financial mistakes and bad decision making by consumers. The question remains how the law can and should respond to such mistakes. Is regulation needed to protect consumers against their own rash or bad decision making?

Although there is no straightforward answer to this question, we discern a number of factors that need to be weighed in the decisions of policy makers (Part 4a). On the basis of the analysis of financial literacy in made in Part 3, furthermore, a few more concrete recommendations can be made with regard to the regulation of consumer credit law through the Consumer Credit Directive and the MiFID (Part 4b).

Financial Literacy: Regulation or No Regulation?

In economics, two viewpoints vie for contention when it comes to solving the problem of financial mistakes. On the one hand, neoclassical economists argue that markets will correct such mistakes through two factors: consumer learning and education efforts by sellers (Epstein 2006, pp. 810-816; Lusardi 2008, pp. 11-14; Moloney 2010, pp. 375-376). On the other hand, behavioural economists contend that learning effects are limited for nonstandardized products - such as complex financial services - and that sellers may not have sufficient incentive to educate consumers, e.g., in cases where this harms their competitive position in the market (Bar-Gill 2008a, pp. 754-761), which strengthens the argument in favour of regulation.

\footnotetext{
$\overline{55}$ Students with a Moroccan or Turkish ethnic background performed worse on a financial literacy test compared to native Dutch students.
} 
It is hard to give a definitive answer as to which view, education versus regulation, should prevail. First, economic theory can only provide context-specific answers. What this means is that whilst learning and competition may well alleviate mistakes in one market, this might not happen in another market (Bar-Gill 2008a, p. 751). Whether the European consumer credit market would benefit from more or lesser regulation, therefore, is an empirical question. Without further evidence on (1) whether financial mistakes are persistent and (2) whether this should be attributed to financial illiteracy of consumers or (additionally) to other factors, we cannot conclude that we are dealing with systematic mistakes for which regulation can potentially provide a solution. Although the studies discussed in Part 3 indicate that financial literacy is a problem in Western European countries, further research is needed to determine the extent of the problem and whether other factors can be responsible for the mistakes that consumers make.

Second, even with the evidence that financial mistakes are persistent in the EU consumer credit market and that the occurrence of such mistakes is to be blamed on financial illiteracy, we still do not know whether regulation is the answer to the problem. Although economic theory - in particular behavioural economics - suggests that regulation can alleviate market failures, there is little consensus with regard to the form that this should take. Several options are open. The least intrusive form currently seen in regulation is that of information duties imposed on providers. The basic idea is that such duties can alleviate the information asymmetry between providers and consumers. However, a lot will depend on the content of these information duties. If we are seeking to solve the problem of financial illiteracy, it is not enough to simply provide information about product characteristics. Consumers will not have the necessary skills to interpret this information and to make a balanced decision on the basis of it. Hence, regulation focusing on information duties should perhaps take other forms in order to be successful: Information can relate not only to the attributes of a product but also, it has been suggested, to individual uses of the product (Bar-Gill 2008a, p. 754). Another option - often seen in addition to information duties - is to take a more intrusive, paternalistic approach to ensure consumer protection. If information provision is insufficient to enable consumers to make responsible financial decisions, regulation can be used to "protect them against themselves." Alternative, more paternalistic options are warning duties or duties to refuse credit to those who cannot afford it. Finally, one may wonder whether ex ante regulation through public law is desirable or whether ex post private law regulation is more appropriate. The former could prevent consumer financial mistakes, but has the disadvantage that it involves compliance costs and that it could stifle innovation. The latter, on the other hand, compensates consumers only after mistakes have been made and losses suffered. Moreover, it may_-depending on the requirements of national law — put a heavy burden on consumers to prove that they were wronged and deserve compensation. ${ }^{56}$

Third, it may be that a distinction needs to be made between simple credit agreements and combined products (e.g., credit combined with investment or insurance). As we saw in Part 2, national laws adopt different views: Dutch law appears to be protective across the board, adopting duties of care towards consumers for credit agreements and investment transactions; English law is on the other extreme and appears very reluctant to acknowledge any duty of care; and German law is in the middle, adopting duties of care with regard to investment products but showing reluctance to be similarly strict with regard to simple credit agreements. Such differences may be explained by policy reasons. Dutch law, for example, imposes a duty to deny credit where there is a risk of over-indebtedness in order to prevent financial hardship for the most vulnerable, low-income consumers (AFM 2006). Such a duty

$\overline{{ }^{56} \text { Compare the cases discussed in Part } 2 .}$ 
can also support other policy goals, e.g., the stability of the financial market. However, a contrary effect is that it may limit the availability of credit to certain groups in society (Moloney 2010, p. 77) ${ }^{57}$ For investment products, other considerations are at play: Can consumer access to investment products be considered as vital for the welfare of society as the access to credit? On the other hand, why should we deny consumer investors access to a market in which they may enjoy significant profits? (cf. Moloney 2010). ${ }^{58}$ The balance between such policy considerations is not an easy one to strike.

Despite these reservations, the evidence from financial literacy studies presented above suggests that there is at least something to say for stricter regulation in the European consumer credit market. Financial mistakes occur on a regular basis, and this seems partly due to the fact that consumers are not sufficiently knowledgeable, experienced, or confident to make sound financial decisions. There is other evidence, moreover, that suggests that the behavioural approach is more realistic than the neoclassical view. Firstly, the view that markets will self-correct financial mistakes through consumer learning and education is subject to important drawbacks. Empirical evidence shows that for debt-related decisions like consumer credit and mortgages, personal education via one-on-one counselling and the settlement of personal objectives, such as a targeted reduction of one's debt, lead to an improvement of consumer financial decision making (OECD 2005, p. 65). For other types of education, the evidence is mixed (Lusardi 2008, p. 11-14). In general, it appears that additional years of (general) education can have positive effects on one's financial behaviour (Cole and Shastry 2009, p. 31). However, specific finance courses do not seem to make much difference (Mandell and Klein 2009, p. 22). A possible explanation is the fact that these courses are often taught for a short period and only cover certain basic concepts (Cole and Shastry 2009, p. 31). An additional problem is that the general education of financially illiterate consumers can be very costly. The combination of a low-literate, heterogeneous, and an often unmotivated target audience and a complex, and dynamic, financial marketplace makes education an expensive exercise with limited chances of success (Willis 2011, p. 430).

Secondly, countering the idea that individuals act rationally, behavioural insights claim that people are found to make decisions under the influence of several biases and heuristics, which can lead to suboptimal results (Luth 2010, p. 47). A heuristic can be defined as a strategy for making decisions that simplifies the problem through the elimination of possible options (Dowling and Chin-Fang 2007, p. 38). Whilst this does not per se lead to mistakes-e.g., a famous experiment showed that consumers can be more likely to reach a decision at all if faced with a more limited number of options, in that case between different flavoured jams (Iyengar and Lepper 2000) - it may result in biases. A bias is defined by behavioural economists as a decision outcome that is systematically different from rational choice predictions (Luth 2010, p. 111). The simplification of complex decisions can thus lead to errors in some decision-making processes (Gigerenzer 1991; Tversky and Kahneman 1974). Some examples of such biases that are relevant to the consumer credit market are:

\footnotetext{
${ }^{57}$ See also above, p. 4.

${ }^{58}$ The influence of industry lobbying with regard to such issues should also not be underestimated; see, e.g., the banks' willingness to provide mortgage credit to a wide range of consumers (Council of Mortgage Lenders UK 2011). It should be noted, in this regard, that losses relating to investment products will mostly fall on consumers rather than on the banks that facilitated the transactions and that for mortgages, the banks have a security right in the pledged real estate. The risk of consumer default on simple credit, on the other hand, lies with the banks.
} 
- Overconfidence: It is common knowledge that individuals more often think they are right than they actually are. In addition, people often assume that a negative event, like becoming unemployed or declining housing prices, will not happen to them. In other words, they underestimate the probability of unpleasant events. On top of this, people think that they are in control with regard to decisions where a component of uncertainty is involved, even though there are uncontrollable factors involved. This "illusion of control" strengthens optimism (Capuano and Ramsay 2011, p. 132). According to Capuano and Ramsay (2011), overconfidence could contribute to problems with overindebtedness and on time repayment of debt (p. 162). Kilborn discusses the fact that the overconfidence bias is an important factor that contributed to the increase in household leverage in the USA (Kilborn 2005, p. 18).

- Myopia: Who of us does not remember the story of the grasshopper and the ant? Humans are biased by preferences in time and often prefer a benefit now to a benefit in the future. This problem of short-term orientation is referred to as myopia (Sunstein 2006, p. 252). This short-sightedness can decrease the level of a person's self-control with respect to the acquisition of debt (Epstein 2006, p. 125). Sunstein also argues that myopia can lead to excessive borrowing behaviour (Sunstein 2006, p. 251).

- Framing: The information about a financial product can either be presented or "framed" in a positive or a negative form. Tversky and Kahneman (1981) were amongst the first to study the influences of framing on decision making. Their study revealed that when an almost similar (monetary) exercise was framed in different ways (for example gains versus losses), significant shifts in preference took place (Tversky and Kahneman 1981, p. 457). Moreover, lenders may seek to limit comparison shopping, enabling them to add exploitative terms in the transaction (McCoy 2005, p. 734). With respect to the understanding of mortgage terms by consumers, framing can be an important factor of influence. Different types of information provision lead to different shifts in preferences by consumers (Bar-Gill 2008b, p. 42). The technique of framing is nowadays widely used in the (financial) marketplace (McCoy 2005, p. 737), and it is often associated with framing debt-related problems like over-indebtedness and unfair terms (Capuano and Ramsay 2011, p. 161).

- Payment/interest bias: The effective annual interest rates of loans are often underestimated by the consumer. This misjudgement could have serious complications. Stango and Zinman found that biased households pay a higher interest rate than unbiased households for loans acquired by a financial company. In addition, they found a strong correlation between the bias and increased borrowing, less saving, short-term orientation, and low net worth (Stango and Zinman 2009). The bias is strong for short-term loans and is caused by the fact that consumers on average have difficulties with exponential functions associated with interest compounding (Stango and Zinman 2009, p. 2833).

- Self-attribution: The human ego and the issue of self-attribution is another frequently occurring bias. People are in general quite satisfied with themselves. An individual will often review past decisions in a biased way in order "to make them feel better about themselves" (Capuano and Ramsay 2011, p. 131). Where the ego gets in the way, it is hard to reflect on one's behaviour in a critical and objective way. Financial mistakes made in the past are then often blamed on external circumstances (Haslem 2010, p. 29). A consequential hazard is that this prevents people from learning from past mistakes.

Recognizing that individual behaviour is steered not only by rational motives but also by these biases can explain why financial mistakes continue to occur. Consumers are likely to 
find it hard to assess the suitability of (complex) financial products. Even educated consumers may fall foul to mistakes, simply because they overestimate their chances of success or are attracted to the possibility of making a quick profit. Although many of such decisions are regarded in law to fall under the own responsibility of consumers - as discussed in Part 2 - one may wonder whether progressive insights on financial (il)literacy and other behavioural influences should not persuade policy makers to opt for stricter regulation, either through public law or through private law.

\section{Financial Literacy and European Consumer Credit Law}

What does this mean for European consumer credit law? Subject to the reservations made in Part $4 \mathrm{a}$, it is arguable that regulation can go some way towards addressing systematic financial mistakes in the EU market for retail financial services. For example, information and disclosure duties can help consumers make a realistic assessment of the costs and risks of credit services (Bar-Gill 2008a, p. 797 ff.). In addition, further protection can be introduced in the form of advice duties or duties to warn, which we see in the MiFID. Finally, besides public law regulation, private law can offer ex post protection to consumers who have made a bad financial decision and have suffered losses in result. The exact form and content of such regulation should be decided on the basis of further empirical research and should be subject to review on a regular basis. Limiting the enquiry for now to the above evaluation of financial literacy, and looking at the case law discussed in Part 2, we make some tentative recommendations as to how the current regulation of consumer protection can be improved.

It is important to stress again at this point that the decision to introduce new regulation always involves a cost/benefits calculation. ${ }^{59}$ We recognize that credit fulfils an important social and economic role in enhancing the welfare of society and that regulation limiting the availability of credit may be more costly than beneficial. However, bearing in mind the lessons from behavioural economics, legal intervention can be justified where consumer mistakes lead to substantial welfare costs in a specific market (Bar-Gill 2008a, p. 753754). ${ }^{60}$

For the EU consumer credit market, the evidence from behavioural studies suggests that financial literacy is, if not the only, at least a significant factor in financial mistakes made by consumers in the Netherlands, the UK, and Germany. On that ground, in our view, a case can be made for adjustments to existing protection which-bearing in mind the costs of regulation - should be specifically targeted at areas in which financial mistakes systematically occur.

The regulatory improvements that we propose are specifically targeted at a group of consumers that we find, on the basis of the evidence from the case law and from behavioural studies, are systematically prone to making financial mistakes: low-income, low-educated consumers. ${ }^{61}$ This group is not only often affected by such mistakes but is also hit the hardest when risks materialize. The risky credit/investment schemes which gave rise to the Dexia litigation, for example, were mostly sold to this vulnerable group of consumers. The

\footnotetext{
59 Above, p. 4.

${ }^{60}$ An economic impact assessment may be required to determine the costs and benefits of new regulation in a particular market.

${ }^{61}$ See the studies presented above, in particular p. 16. On predatory lending, see also McCoy (2005). Although other groups also suffer from low levels of financial literacy, e.g., women, young people, or certain ethnic groups, it is harder in those cases to make generalizations about their financial position and, hence, their vulnerability in case of financial mistakes.
} 
harm they suffer often is not only of a financial nature but also impacts much broader on their welfare and even often on their health. ${ }^{62}$ It is not surprising, then, that the Dutch Supreme Court sought to protect them by imposing a duty of care on the bank which included, inter alia, a duty to investigate the consumer's financial position. ${ }^{63}$ The imposition of such a duty of care, in this case ex post through private law, can perhaps even better be achieved ex ante through public law. As long as duties on credit providers are limited, so that competition is not stifled, this route is to be preferred as it protects consumers from costly and cumbersome proceedings in private law courts to obtain compensation for loss resulting from risky credit products.

The results from the behavioural studies that were analysed in Part 3 of the article make clear that focusing on more information disclosure is insufficient to prevent financial mistakes. Most consumers simply lack sufficient relevant financial skills and knowledge. As a result, they will be ill-equipped to understand the complex nature of the disclosed information. That is particularly true for certain groups of consumers, including the lower educated. The argument that education can enhance the financial literacy skills of this group has some support, as we have seen in Part 4a, but does not seem a very realistic option. Only extensive one-on-one counselling and mutual financial planning between consumer and company could improve decision making (OECD 2005, p. 65). However, this intensive personal interaction between consumer and company is very expensive and time-consuming and therefore hard to implement on a large scale.

Which changes would this involve in current regulation? Counter to the trend of reliance on information duties prevalent in EU consumer law, we propose that for such cases, a policy of "responsible lending" and "suitability" can be reinforced through improvements in consumer credit law, in particular in the MiFID's advice and warning regime. ${ }^{64}$ That of course leaves the question of what should be understood by these abstract standards. For consumer credit, the relevant regulation at the EU level is laid down in the Consumer Credit Directive and in the MiFID. The first applies generally to a wide range of consumer credit agreements; the latter, specifically to credit agreements with investment firms. ${ }^{65}$ In both, the general starting point is that consumers should be enabled to decide for themselves whether a credit or investment product suits their particular needs and financial situation. ${ }^{66}$ This focus on the rational "average consumer" is balanced by some protective provisions, which we believe should be extended with an eye to protecting the vulnerable group of lowincome, low-educated consumers.

\section{Consumer Credit Directive}

The Consumer Credit Directive imposes two duties on providers that should help consumers in this decision-making process: information duties (cf. Art. 5(6), see in particular Artt. 4-6) and a creditworthiness test (Art. 8). Although Art. 5(6) leaves room for Member States to

\footnotetext{
${ }^{62}$ Research shows that there are relationships between being indebted and decreased psychological well-being (Brown et al. 2005). In addition, correlations have been found between (over)indebtedness and physical issues like bad health and even obesity (Keese and Schmitz 2011; Münster et al. 2009).

63 See p. 7.

64 This would fit with the notion of "asymmetric paternalism" in which paternalistic interventions are limited to situations where the law is likely to generate large benefits for individuals because they are prevented from suffering significant losses, but imposes only small costs on individuals who can be expected to behave rationally and for whom the intervention is unnecessary; compare Ogus (2010).

${ }^{65}$ See n. 16 above.

66 cf. Consumer Credit Directive, Art. 5(6); MiFID, Art. 19(5).
} 
"adapt the manner by which and the extent to which...assistance is given," until now, Member States have not been inclined to impose stricter advice duties on providers. Not only is this limited duty in line with the idea of the rational, empowered consumer that is central to EU consumer law, but it also leads to considerable cost-saving on advice and counselling and is therefore in the public interest. ${ }^{67}$ The tide may be turning, however, with regard to mortgage credit; in the current debate on "responsible lending" in the mortgage credit market, more emphasis appears to be placed on the need for adequate advice (see, e.g., FSA 2011, pp. 28-29).

Article 8, which obliges credit providers to investigate the creditworthiness of consumers, could potentially be used to protect vulnerable, low-income consumers. Problematic is that the provision itself does not specify which consequences should be attached to the consumer's lack of creditworthiness. Although the consumer image of a consumer who is able to digest information is not easily matched with a prohibition of concluding a credit contract with such a non-creditworthy consumer (Reifner 2004, p. 88; Grundmann and Hollering 2008 , p. 50), it is defendable that the Directive would allow a warning to the consumer on the basis of recital 26 (Rott 2009, p. 199). The provider has to make clear that the product is risky and therefore is not suitable for the client's financial situation. The question is, however, whether such a duty to warn would be a sufficient way of intervention. For some consumers, a negative advice may be enough ground to refrain from entering into a credit agreement. Nevertheless, a significant group of consumers may still-for example because of a lack of financial literacy and/or behavioural biases-decide to go ahead with the transaction and acquire a risky financial product. For them, a warning duty would not be sufficient. Instead, a duty for the provider to deny credit to this category of consumers could be a solution. ${ }^{68}$ Such a duty is in fact included in Article 14 of the proposal for a Mortgage Credit Directive and would require a denial of credit to any category of consumer, not just the most vulnerable. Moreover, some national systems already adopt such a protective stance with regard to consumer credit. As we saw in Part 2, Dutch law-unlike German and English law - stipulates that credit should be denied where the assessment of a consumer's creditworthiness indicates that the proposed credit agreement puts him at risk of overindebtedness. $^{69}$

We realize that this type of regulatory intervention is radical. It restricts the autonomy of contracting parties in the financial marketplace and goes against the idea-prevalent in existing law-that consumers foremost are responsible for their own choices. Nevertheless, a duty to deny complex, risky products to vulnerable groups of consumers could serve as the ultimum remedium in European consumer protection law. This duty should therefore not be applied to all consumers who ignore the advice from a financial company after a negative creditworthiness assessment. Consumers who can be shown to possess sufficient knowledge or financial literacy skills, or who are sufficiently creditworthy, should get the benefit of the doubt. The relevant circumstances of a particular consumer and the preferred product should determine whether the professional party has to deny the contract. ${ }^{70}$

\footnotetext{
${ }^{67}$ Compare Kamerstukken II 2003-2004, 29 507, nr. 3, p. 86.

${ }^{68}$ Such a duty exists for example with regard to "margin requirements" in Dutch investment law; see above, $p$. 8. Note also that this would involve an amendment of the Directive, which is aimed at maximum harmonization.

${ }^{69}$ See p. 8 above.

70 The income of the consumer could, for example, serve as one of these relevant circumstances. One could think of situations where low-income consumers intend to borrow more than twice their annual income. The maximum financial risk that a consumer runs with a particular product could also be a relevant aspect here.
} 
The costs of systematic financial mistakes made by low-income, low-educated consumers, therefore, may warrant a different balancing of interests and may justify stronger duties of care from credit providers to consumers. The Consumer Credit Directive can reflect this by introducing either stronger advice duties, or even a duty to deny credit where a consumer does not comprehend the riskiness of a product or is not in a financial position that affords him taking the risk.

\section{Markets in Financial Instruments Directive}

The MiFID's regime, as we have seen, focuses on the EU notion of the "average consumer" who is "reasonably well-informed and reasonably observant and circumspect." reflected in the provisions of the MiFID and their further elaboration in the MiFID Implementation Directive. ${ }^{72}$ It is important to note a differentiation in protection duties between general investment (or credit) services and several specific B2C investment relationships. For lowincome, low-educated consumers, protection can be strengthened in either format.

In relation to general services that do not imply a determination of the investment decision by the service provider - such as services only helping the investor executing transactions he himself has decided to enter into, without being advised to do so by the firm (Kruithof 2011, p. 133) - investment service providers are obliged to ask the (potential) client to provide information regarding his knowledge and experience in the investment field relevant to the specific type of product or service offered or demanded. The aim of this is to enable the provider to assess whether the investment service or product envisaged is appropriate for the client and, if not, to warn the client. ${ }^{73}$ The final responsibility lies with the client, however, for appropriateness, in this case, refers to the ability of the client to decide independently on the suitability of the investment decision (Kruithof 2011, p. 134). The "average consumer" to which these rules refer, therefore, is the empowered consumer of EU law who should be able to make an appropriate decision on the basis of the information provided by the bank or investment firm. For the vulnerable group of low-income, low-educated consumers, it would seem that a warning is not enough and that - as suggested for the Consumer Credit Directive - a duty to deny credit could, for the weakest groups, be an appropriate additional way of regulation. That kind of protection could, for example, have prevented the large-scale losses and the ensuing litigation in the Dexia cases in the Netherlands.

Existing protection is already stronger for specific types of transactions or specific types of bank-client relationships, such as advice agreements or portfolio management under the MiFID. ${ }^{74}$ In these relationships, the bank (or investment firm) is under an active duty to advise the client or to take investment decisions on his behalf. Investment service providers are more involved in the decision-making process in these cases and will actively have to assess the suitability of a product or service for their client. Obligations to that effect are laid down in Article 19(4) of the MiFID. On the basis of this provision, investment firms are obliged to obtain the necessary information regarding the (potential) client's (1) knowledge and experience in the investment field relevant to the specific type of product or service; (2)

\footnotetext{
$\overline{71}$ See Gut Springenheide (n. 23).

72 Directive 2006/73EC implementing Directive 2004/39/EC of the European Parliament and of the Council as regards organizational requirements and operating conditions for investment firms and defined terms for the purposes of that Directive [2006] OJ L241/26. Note that the MiFID also distinguishes between consumer and professional investors; see Kruithof (2011), in particular p. $123 \mathrm{ff}$.

73 See Art. 19(5) MiFID. Note that the term "client" applies not only to consumers but also to professional parties. Further discussion of this category of investors is outside the scope of this contribution. For a detailed discussion, see Kruithof (2011, p. $116 \mathrm{ff})$.

${ }^{74}$ Cf. Art. 19(4) MiFID.
} 
financial situation; and (3) investment objectives, all with an eye to recommending products or services that are suitable to the (potential) client. For these relationships, therefore, an exception is made to the "average consumer"; standard and stricter duties are imposed on banks and investment firms in terms of information provision, advice duties, and the assessment of suitability. ${ }^{75}$

The idea that closer involvement with a client's investment decisions requires greater responsibility from banks and investment firms towards their clients is reinforced by the general conduct of business rule on which Article 19 of the MiFID is based. That rule is reflected in Article 19(1): An investment service provider is obliged to "act honestly, fairly and professionally in accordance with the best interests of its clients." This rule can be described as an "umbrella rule of conduct" (Kruithof 2011, p. 147) encompassing not only the duties specified in Article 19(2)-(8) of the MiFID but also reflecting the general rule of care that exists in different manifestations in the contract and tort laws of the Member States. It is a duty of care and loyalty, therefore, that encompasses not only all the duties relating to information gathering, advising, or counselling, which are accessory to the service provided to the client, but also the duty of the service provider to comply with the private law duties that follow from the contractual relationship with a client (Cherednychenko 2011, p. 262 ff.; Kruithof 2011).

For low-income, low-educated consumers, this extended protection can be of some relevance, in particular if they choose to seek advice. ${ }^{76}$ In that case, the credit provider is obliged to investigate the consumer's knowledge and experience and his financial situation. As with the Consumer Credit Directive, however, the consequences to be attached to this are not entirely clear. One would expect- since that is the standard for general services provided to the "average consumer" under Art. 19(5) of the MiFID - that credit providers at least have a duty to warn if the product is not suitable. In light with the foregoing, it would be appropriate to also include a duty to deny credit in cases where low-income, low-educated consumers intend to overplay their hand by choosing a product that is not suitable to their financial position. It is good to stress again that such a duty is in our opinion the ultimum remedium in order to protect the most vulnerable group of financial consumers. The circumstances of each individual case determine whether credit providers should make this call and deny credit.

\section{Concluding Remarks}

Although mistakes are made, they can often be corrected. In this article, we have argued that financial mistakes resulting from a lack of financial literacy on the part of consumers can and should be anticipated and avoided through legal regulation. We are aware, however, of the costs of regulation and emphasize that regulation should only be introduced in cases where consumer mistakes lead to substantial welfare costs in a specific market. For the EU consumer credit market, there is ever more evidence supporting the view that consumers lack financial literacy and that they, in result, are prone to bad decision making with regard to financial products. The most vulnerable groups - such as low-income, low-educated consumers - in our view, deserve greater protection through regulation that provides

\footnotetext{
${ }^{75}$ This is reflected also in the explanatory memorandum for the Dutch legislation implementing the MiFID; see Kamerstukken II 2005-2006, 29 708, nr. 19, p. 509, and Kamerstukken II 2003-2004, 29 507, nr. 3, p. 87.

${ }^{76}$ Note that consumers are expected to realize for themselves if and when they need advice in order to make a sound decision; Kamerstukken II 2003-2004, 29 507, nr. 3, p. 86.
} 
financial companies with an extensive duty to warn and, if necessary, even a duty to prevent particular consumers from entering into overly risky agreements.

Open Access This article is distributed under the terms of the Creative Commons Attribution License which permits any use, distribution, and reproduction in any medium, provided the original author(s) and the source are credited.

\section{References}

Adkins, N. R., \& Ozanne, J. L. (2005). The low literate consumer. Journal of Consumer Research, 32, 93105 .

Autoriteit Financiële Markten (AFM). (2006). Verantwoorde kredietverstrekking 2006.

Bar-Gill, O. (2008a). The behavioral economics of consumer contracts. Minnesota Law Review, 92, 749-802.

Bar-Gill, O. (2008b). The law, economics and psychology of subprime mortgage contracts. New York University Law and Economics Working Paper, No. 161.

Ben-Shahar, O., \& Schneider, C. E. (2010). The failure of mandated disclosure. University of Chicago, The Law School John M. Olin Law \& Economics Research Paper No. 516; University of Michigan Law School Law \& Economics, Empirical Legal Studies Center Paper No. 10-008. Retrieved from http:// ssrn.com/abstract=1567284. Accessed 21 May 2012.

Boeri, T., \& Guiso, L. (2008). The subprime crisis: Greenspan's legacy. In A. Felton \& C. Reinart (Eds.), The first global financial crisis of the 21st century. VoxEU.org. Accessed 21 May 2012.

Bond, R., Kutsenko A., \& Lozitskaya, N. (2010). Financial literacy and awareness in Ukraine: facts and findings. Report USAID Financial Sector Development Project (FINREP).

Boom, W. H. van, \& Lindenbergh, S. D. (2010). Effectenlease: dwaling, zorgplicht en schadevergoeding. Ars Aequi, 188-196.

Braspenning, J. J. A. (2012). Your future starts today, not tomorrow: an explanatory study of financial literacy and debt-related behavior among students in the Netherlands. Retrieved from http://papers.ssrn.com/sol3/ papers.cfm?abstract_id=2040913. Accessed 21 May 2012.

Braunstein, S., \& Welch, C. (2002). Financial literacy: an overview of practice, research, and policy. Federal Reserve Bulletin, 88, 445-457.

Brown, S., Taylor, K., \& Wheatley Price, S. (2005). Debt and distress: evaluating the psychological cost of credit. Journal of Economic Psychology, 26, 642-663.

Bucher-Koenen, T., \& Lusardi, A. (2011). Financial literacy and retirement planning in Germany. MEA Discussion Paper No. 239-11. Retrieved from http://ssrn.com/abstract=1813744. Accessed 21 May 2012.

Bucks, B. K., \& Pence, K. M. (2008). Do borrowers know their mortgage terms? Journal of Urban Economics. Retrieved from http://works.bepress.com/karen_pence/5. Accessed 21 May 2012.

Capuano, A., \& Ramsay, I. (2011). What causes suboptimal financial behaviour? An exploration of financial literacy, social influences and behavioural econcomics. Research Report, Financial literacy Project. University of Melbourne. Accessed 21 May 2012.

Cherednychenko, O. O. (2011). Conceptualising unconscionability in the context of risky financial transactions: how to converge public and private law approaches? In M. Kenny, J. Devenney, \& L. Fox O’Mahony (Eds.), Unconscionability in European private financial transactions (pp. 246-274). Cambridge: Cambridge University Press.

Cole, S., \& Shastry, G. K. (2009). Smart money: the effect of education, cognitive ability, and financial literacy on financial market participation. Harvard Business School Working Paper, No. 2009-071. Accessed 21 May 2012.

Council of Mortgage Lenders. (2011). UK industry briefing on the proposed Directive of the European Parliament and of the Council on Credit Agreements relating to residential property. Retrieved from http://www.cml.org.uk. Accessed 21 May 2012.

Disney, R. F., \& Gathergood, J. (2011). Financial literacy and indebtedness: new evidence for U.K. consumers. University of Nottingham Working Paper. Retrieved from http://ssrn.com/abstract=1851343. Accessed 21 May 2012. 
Dixon, M. (2006). Rethinking financial capability. Lessons from economic psychology and behavioural finance. Institute for Public Pension Policy Research. Retrieved from www.ippr.org. Accessed 21 May 2012.

Dowling, J. M., \& Chin-Fang, Y. (2007). Modern developments in behavioural economics: social science perspectives on choice and decision making. Singapore: World Scientific Printers.

Epstein, R. A. (2006). Behavioural economics: human errors and market corrections. University of Chicago Law Review, 73, 111-132.

Epstein, R. A. (2008). The neoclassical econimics of consumer contracts. Minnesota Law Review, $92,803$.

European Commission. (2010). Public consultation. Review of the Markets in Financial Instruments Directive (MiFID). Brussels: DG Internal Market and Services.

European Commission. (2011). Proposal for a Directive of the European Parliament and of the Council on Credit Agreements relating to residential property. COM(2011) 142 final.

Fazli Sabri, M., MacDonalds, M., Hira, T. K., \& Masud, J. (2010). Childhood consumer experience and the financial literacy of college students in Malaysia. Family and Consumer Sciences Research Journal, 38, 455-467.

FOS (2010). Annual Review 2009/2010. London: Financial Ombudsman Service.

FSA (2006). Levels of financial capability in the UK: results of a baseline survey. London Financial Services Authority.

FSA (2009). The assessment and redress of payment protection insurance complaints, CP09/23. London: Financial Services Authority.

FSA (2011). Mortgage Market Review, CP11/31. London: Financial Services Authority.

Gathergood, J. (2012). Self-control, financial literacy and consumer over-indebtedness. Journal of Economic Psychology, 33, 590-602.

Gerardi, K. S., Goette, L. F., \& Meier, S. (2010). Financial literacy and subprime mortgage delinquency: evidence from a survey matched to administrative data. Federal Reserve Bank of Atlanta Working Paper Series No. 2010-10. Retrieved from http://ssrn.com/abstract=1600905. Accessed 21 May 2012.

Gigerenzer, G. (1991). How to make cognitive illusions disappear: beyond 'heuristics and biases'. European Review of Social Psychology, 2, 83-115.

Grundmann, S., \& Atamer, Y. M. (Eds.). (2010). Financial services, financial crisis and general European contract law. Failure and challenges of contracting. Alphen aan den Rijn: Kluwer Law International.

Grundmann, S., \& Hollering, J. (2008). EC financial services and contract law-developments 2005-2007. European Review of Contract Law, 4, 45-64.

Haslem, J. E. (2010). The new reality of financial advisors and investors. Journal of Investing, 19, 23-30.

Howells, G. (2010). The consumer credit litigation explosion. LQR, 126, 617-644.

Hung, A. A., Parket, A. M., \& Yoong, J. K. (2009). Defining and measuring financial literacy. Rand Corporation Working Paper. Retrieved from http://www.rand.org/pubs/working_papers/2009/RAND_WR708.pdf. Retrieved from http://ssrn.com/abstract=1498674. Accessed 21 May 2012.

Iyengar, S. S., \& Lepper, M. R. (2000). When choice is demotivating: can one desire too much of a good thing? Journal of Personality and Social Psychology, 79, 995-1006.

Jansen, K. J. O. (2010). De eigen verantwoordelijkheid van de financiële consument. Weekblad voor Privaatrecht, Notariaat en Registratie (WPNR), 623.

Keese, M., \& Schmitz, H. (2011). Broke, ill, and obese: the effect of household debt on health. SOEP Paper, No. 350. Retrieved from http://ssrn.com/abstract=1750216. Accessed 21 May 2012.

Kilborn, J. (2005). Behavioural economics, overindebtedness and comparative consumer bankruptcy: searching for causes and evaluating solutions. Emory Bankruptcy Developments Journal, 22, 13-45.

Kruithof, M. (2011). A differentiated approach to client protection: the example of MiFID. In S. Grundmann \& Y. M. Atamer (Eds.), Financial services, financial crisis and general European contract law. Failure and challenges of contracting (pp. 105-162). Alphen aan den Rijn: Kluwer Law International.

Lusardi, A. (2008). Financial literacy: an essential tool for informed consumer choice? NBER Working Paper Series, No. w14084. Accessed 21 May 2012.

Lusardi, A., \& Mitchell, O. S. (2007). Financial literacy and retirement preparedness: evidence and implications for financial education. Business Economics, 42, 35-44.

Lusardi, A., \& Tufano, P. (2009). Debt literacy, financial experiences, and overindebtedness. NBER Working Paper Series, No. w14808. Accessed 21 May 2012.

Luth, H. A. (2010). Behavioural economics in consumer policy. The economic analysis of standard terms in consumer contracts revisited. Doctoral thesis, Erasmus University, Rotterdam.

Mak, V. (2011). The 'average consumer' of EU law in domestic litigation: examples from consumer credit and investment cases. Paper presented at the The Involvement of EU Law in Private Law Relationships Conference, Oxford, September 2011. Retrieved from http://ssrn.com/abstract=1960603.

Mandell, L., \& Klein, L. S. (2009). The impact of financial literacy education on subsequent financial behavior. Journal of Financial Counselling and Planning, 20, 15-24.

McCoy, P. A. (2005). A behavioural analysis of predatory lending. Akron Law Review, 38, 725-739. 
Moloney, N. (2010). How to protect investors. Lessons from the EC and the UK. Cambridge: Cambridge University Press.

Monticone, C. (2010). How much does wealth matter for financial literacy acquisition? Journal of Consumer Affairs, 44, 403-422.

Münster, E., Rüger, H., Ochsmann, E., Letzel, S., \& Tochske, A. M. (2009). Over-indebtedness as a marker of socioeconomic status and its association with obesity: a cross-sectional study. BMC Public Health, 9, 286.

O'Donnell, N. (2009). Consumer financial capability: a comparison of the UK and Ireland. Central Bank of Ireland Research Technical Papers, 4/RT/09. Accessed 21 May 2012.

OECD (2005). Improving Financial Literacy: Analysis of Issues and Policies. Paris: Organisation of Economic Cooperation and Development.

Oehler, A., \& Werner, C. (2008). Saving for retirement - a case for financial education in Germany and UK? An economic perspective. Journal of Consumer Policy, 31, 253-283.

Ogus, A. (2010). The paradoxes of legal paternalism and how to resolve them. Legal Studies, 30, 61-73.

Pahnke, L., \& Honekamp, I. (2010). Different effects of financial literacy and financial education in Germany. MPRA Paper 22900. Retrieved from http://mpra.ub.uni-muenchen.de/22900/1/MPRA_paper_22900.pdf. Accessed 21 May 2012.

Reifner, U. (2004). Konsumentenkreditrichtlinie im Europaparlament-Zurück zu den Siebzigern? Verbraucher und Recht, 85-89.

Remund, D. L. (2010). Financial literacy explicated: the case for a clearer definition in an increasingly complex economy. Journal of Consumer Affairs, 44, 276-295.

Rott, P. (2009). Consumer credit. In H.-W. Micklitz, N. Reich, \& P. Rott (Eds.), Understanding EU consumer law (pp. 177-214). Oxford: Hart.

Stango, V., \& Zinman, J. (2009). Exponential growth bias and household finance. The Journal of Finance, 64, 2807-2849.

Sunstein, C. R. (2006). Boundedly rational borrowing. The University of Chicago Law Review, 73, 249-270.

Tversky, A., \& Kahneman, D. (1974). Judgment under uncertainty: heuristics and biases. Science, 185, 1124 1131.

Tversky, A., \& Kahneman, D. (1981). The framing of decisions and the psychology of choice. Science, 211, $453-458$.

Tzankova, I. (2012). Funding of mass disputes: lessons from the Netherlands. George Mason Journal of Law, Economics and Policy (in press).

Rooij, M. van (2006). Limited financial literacy among Dutch households. DNB Quarterly Bulletin.

van Rooij, M., Lusardi, A., \& Alessie, R. (2007). Financial literacy and stock market participation. NBER Working Paper No. 13565. Accessed 21 May 2012.

van Rooij, M., Lusardi, A., \& Alessie, R. (2009). Financial literacy and retirement planning in The Netherlands, DNB Working Paper No. 231/2008.

van Rooij, M., Lusardi, A., \& Alessie, R. (2011). Financial literacy, retirement preparation and pension expectations in the Netherlands. DNB Working Paper No. 289. Accessed 21 May 2012.

Willis, L.E. (2011). The financial education fallacy. American Economic Review: Papers and Proceedings 2011, 101:3. 